\title{
Onoma 55
}

Journal of the International Council of Onomastic Sciences

ISSN: 0078-463X; e-ISSN: 1783-1644

Journal homepage: https://onomajournal.org/

\section{Are contemporary Bulgarian personal names still indicative of a Bulgarian identity?}

\section{Anna Choleva-Dimitrova ${ }^{a}$, Nadezhda Dancheva ${ }^{a}$, Maya Vlahova-Angelova ${ }^{a, *}$, Gergana Petkova ${ }^{b}$}

${ }^{a}$ Onomastics Department, Institute for Bulgarian Language, Bulgarian Academy of Sciences, Sofia, Bulgaria

${ }^{\mathrm{b}}$ Department of Language and Specialized Training (DESO), Medical University Plovdiv, Bulgaria

To cite this article: Choleva-Dimitrova, Anna \& Dancheva, Nadezhda \& VlahovaAngelova, Maya \& Petkova, Gergana. 2020. Are contemporary Bulgarian personal names still indicative of a Bulgarian identity? Onoma 55, 247-266. DOI:

10.34158/ONOMA.55/2020/14

To link to this article: https://doi.org/10.34158/ONOMA.55/2020/14

(C) Onoma and the authors.

\section{Article history}

Received on 12 February 2020.

Final form accepted on 28 June 2021.

Published online on 28 July 2021.

* Contact: Maya Vlahova-Angelova, Associate Professor, Onomastics Department, Institute for Bulgarian Language, Bulgarian Academy of Sciences, 52, Shipchenski prohod Blv., Sofia, Bulgaria, mvlahova@ibl.bas.bg 
Are contemporary Bulgarian personal names still indicative of Bulgarian identity?

Abstract: The Bulgarian three-component name system was established in the late 19th century, shortly after the Bulgarian independence. Based on the long-standing Bulgarian tradition, first names, patronymics and family names reveal the ethnic and cultural identity of the name bearers.

This study is synchronic and investigates the effect some current naming practices have on the contemporary Bulgarian onomasticon. Special emphasis is placed on the following issues: diachronic name dynamics, contemporary given-name frequency, name loss, name borrowing, issues regarding hereditary patronymics, and family names and their forms. The research is based on official first and father's name registries and on a corpus of family names from publicly available records.

The main conclusions show that two parallel trends can be delineated: 1) the Bulgarian anthroponymicon looks more international nowadays; 2) the prevalence of onyms traditional for the Bulgarian anthroponymic system among most newborns is proof of the stability of Bulgarian identity.

Keywords: Bulgarian anthroponymicon, forenames, patronyms, family names.

\section{Les noms de personnes en bulgare contemporain, évoquent-ils toujours l'identité bulgare?}

Résumé : Le système anthroponymique bulgare à trois composantes a été établi à la fin du XIXe siècle, après la Libération. Puisqu'ils reposent sur une longue tradition, les prénoms, les patronymes et les noms de famille évoquent l'identité ethnique et culturelle des personnes désignées.

Cette étude synchronique se penche sur l'effet que les pratiques contemporaines de désignation produisent sur l'onomasticon. Une attention particulière y est accordée à la dynamique diachronique des anthroponymes, à la fréquence d'usage des noms contemporains, celle des noms en train de sortir de l'usage courant ou qui sont d'apparition récente. Est considéré aussi pour cette travail un certain nombre de problèmes liés aux patronymes et aux noms de famille héréditaires, et à leur forme. L'étude est basée sur les données recueillies aux registres officiels des prénoms et des patronymes ainsi que sur un corpus de noms de famille constitué depuis des sources publiques de libre accès.

Les grandes tendances relatives à l'anthroponymicon bulgare contemporain se dessinent comme suit : 1 . Composition internationale à échelle significative ; 2 . Tendance parallèle à désigner les nouveau-nés par des noms traditionnels, confirmant ainsi la stabilité de l'identité nationale bulgare.

Mots-clés : Anthroponymicon bulgare, prénoms, patronymes, noms de famille.

\section{Verweisen Zeitgenössische Bulgarische Vornamen noch auf eine Bulgarische Identität?}

Zusammenfassung: Das bulgarische Namensystem aus drei Namenbestandteilen wurde Ende des 19. Jahrhunderts nach der Wiederherstellung der bulgarischen Staatlichkeit eingeführt. Einer langjährigen Tradition folgend weist die Kombination von Vorname, Patronym (Vatersname) und Familienname auf die ethnische und kulturelle Identität der Namensträger hin.

In einer synchronen Perspektive untersucht diese Studie die Auswirkungen der aktuellen Namengebung auf das zeitgenössische bulgarische Namenssystem. 
Besonderes Augenmerk wird auf folgende Themen gelegt: diachrone Namendynamik, zeitliche Häufigkeit von Vornamen, abgegangene Vornamen, neue beliebte Vornamen sowie Fragen in Bezug auf erbliche Vaters- und Familiennamen und deren Formen. Die Studie basiert auf Daten für Vornamen und Vatersnamen aus dem offiziellen Bürgerregister sowie auf einem Korpus von Familiennamen aus öffentlich zugänglichen Quellen.

Die wichtigsten Schlussfolgerungen zeigen zwei parallele Trends: 1) Das bulgarische Anthroponymikon sieht heutzutage internationaler aus. 2) Dass der Mehrheit der Neugeborenen einen im bulgarischen anthroponymischen System traditionellen Vornamen zu geben, ist ein Beweis für die Beständigkeit der bulgarischen Identität.

Schlüsselbegriffe: Bulgarisches Anthroponym, Vornamen, Patronyme, Familiennamen. 


\title{
Are contemporary Bulgarian personal names still indicative of Bulgarian identity? ${ }^{1}$
}

\author{
AnNa Choleva-Dimitrova, NADEZHDa DancheVA, \\ Maya Vlahova-Angelova, Gergana PetKova
}

\section{Introduction}

Bulgarian first, patronymic, and family names reveal the cultural and ethnic sameness of their bearers ${ }^{2}$ and are a key symbol of national identity both in form and content. The present study is focused on the consequences of some contemporary naming practices on the Bulgarian anthroponymic system, as well as on the analysis of the system's three main components - the first, father's, and family name mentioned above - in order to shed light on the processes characteristic of its contemporary state. The research aims to find out whether Bulgarian names are still an "ethnic marker" (Bankova 2008: 3) or whether they have lost their national specificity and are decreasingly reflective of Bulgarian ethnicity. The study will include a synchronic review of the official records for the first, father's, and family names of newborns. The analysis of personal onyms will reveal the changes that the name preferences of Bulgarians are undergoing, as well as the extent to which tradition has been preserved alongside the current anthroponymic trends. The object of investigation in this article is the personal names of newborns in the largest Bulgarian towns of Sofia, Varna, and Plovdiv in 2007 and 2014. Newborns' names will be studied, since this is precisely what will delineate the tendencies related to the shape of the Bulgarian anthroponymic system in the coming years (Choleva-Dimitrova \& Yanev 2015). The examination of patronymic and family names will aim to identify the principal contemporary challenges, mainly brought about by deviations from the accepted norms and the attempts to make them more flexible or modern.

\section{Names in Bulgarian tradition}

Much like one's mother tongue, given names are integral to the development of identity. According to Taylor (1999: 62), identities are, to a large extent, based on what we could call collective social identity: nation,

The present study is conducted under the project "Personal Names in Bulgaria in the Beginning of 21st Century" with the support of the National Science Fund of the Republic of Bulgaria, Grant № КП-06-H-40/10, 10.12.2019.

2 The present survey is devoted exclusively to names of ethnic Bulgarians, since they are the main ethnic group in Bulgaria and form $84.8 \%$ of the total population of the country (NSI, 2011 census (final data)) in which the official language is Bulgarian and the official religion - Eastern Orthodoxy. 
religion, ethnicity, "race," sexual orientation. As a sizeable component of the cultural strata, names encode information about nationality, religion, ethnicity, history, geography, traditions, and beliefs. In that sense, the process of naming newborn Bulgarians has a direct relationship to the creation of a national and European identity. Language is one of the resources with the greatest potential for ethnic formation and unification. Names have an indisputable role in the creation of ethnicity (Krysteva 1998: 31-34). Some names in the Bulgarian three-component system are linked to religion and the religious calendar. Some of them carry information about Bulgarian history - the resurrected names of Bulgarian historical personalities, for example. Most names still identify the bearer's gender. Some first, patronymic, and family names are connected to ethnic or geographical origin, occupation, or folk traditions and beliefs.

The anthroponymic system is known to be one of the more specific and resistant elements of any culture. The contemporary three-component personal name system ${ }^{3}$ composed of first, father's, and family name was officially introduced in Bulgaria in the late 19th century, after independence from Ottoman rule, but its roots are to be found much earlier (Ilchev 2012 [1969]; Kovachev 1987; Choleva-Dimitrova 2017a: 13). In spite of being inherently conservative, it undergoes constant changes.

Under the influence of a variety of factors, traditional Bulgarian naming practices were gradually discarded, which led to a break with tradition and desacralized the process (Krasteva-Blagoeva 1999). Presently, the choice of a given name depends to a large extent on the parents' preferences and their subjective perception of modern and outdated anthroponyms (Kalkanova 1996; Choleva-Dimitrova 2002; Bankova 2008; Yanev 2009; Virkkula 2014; CholevaDimitrova \& Yanev 2015). The patronymic and family name are inherited, but Bulgarian legislation allows the possibility a choice being made with respect to the family name.

There are a number of studies devoted to naming fashions in Bulgaria and the changes brought about by external influences (Kalkanova 1996; CholevaDimitrova 2002; Bankova 2008; Yanev 2009; Virkkula 2014; Choleva-Dimitrova \& Yanev 2015). It is important to note that around the middle of the 20th century, Bulgarians began to equate the modern and the prestigious with the foreign, while traditional ways were increasingly considered obsolete and non-prestigious (Konstantinov 1987; Kalkanova 1996; Choleva-Dimitrova 2002). The preferred anthroponyms thus became the modernized, foreign-sounding ones, mostly formed with borrowed suffixes or through direct loans of foreign versions of traditional names. Another typical pattern may be observed in the so-called hybrid, compromise, or combined names. These arose as a compromise between modernizing a name for prestige and honouring and respecting ancestral traditions (Ilchev 2012 [1969];

3 Each Bulgarian citizen has a first, a father's, and a family name. The first name is given/chosen by the parents, while the patronymic and the family name are inherited from the father. 
Boyadzhiev 1975; Konduktorova-Valkanova 1981; Konstantinov 1987; Chobanov 1990; Krasteva-Blagoeva 1999; Choleva-Dimitrova 2002). As a result, we have witnessed the appearance of onyms such as Lyubozar ${ }^{4}$ (a hybrid of Lyuben and Zarko) (Choleva-Dimitrova 2002: 284), "which contain explicit prestige and an implicit loyalty for the progenitors" (Konstantinov 1987: 43). These tendencies were amplified in the 1990s and did not subside at the turn of the century. This was a time when Bulgarians rebelled against the restrictive rules and laws that limited their freedom to choose a name. ${ }^{5}$ This is how at the onset of the 21 st century, "a name of a foreign origin has become a sign of liberation and non-abidance to norms that have outlived their time" (Bankova 2008: 3).

\section{First names}

\subsection{First names in Sofia during the 20th century}

The periodic changes in the popular names list and the different fashionable trends are explained by a complex interaction between linguistic and social factors that affect the choice of a name (Superanskaya 1973: 42-43; Van Langendonck 1971, 1980; Debus 1997a, 1997b; Koss 1990; Yanev 2009: 53).

One distinctive Bulgarian cultural tradition was to name the firstborn after his or her paternal grandfather or grandmother. It was considered that these babies were being given a name that would renew that of the paternal grandparent. The second child was named after one of the maternal grandparents (Ilchev 2012 [1969]; Yanev 2009; Choleva-Dimitrova \& Yanev 2015). For a long period of time, anthroponyms ${ }^{6}$ with a link to Christianity and domestic ones (related to folk traditions and beliefs) were prevalent. Many of the latter gradually ceased to be part of the contemporary anthroponymic system, and now just a few are present in baby name lists.

The motives behind choosing a first name gradually changed, and by the 1960s-1970s, the centuries-long tradition of naming children after grandparents and great-grandparents was no longer the only, invariable determinant. Name choice was already being decided by parental preferences. One survey carried out in the Bulgarian capital in 1979 revealed that $57 \%$ of newborns in the Serdika district in Sofia were given their grandparents' names, 30\% - names liked by the parents, and 23\% were named after another individual (CholevaDimitrova 2002). As a result, the most common onyms also changed, and anthroponyms such as Mariya, Albena, Silviya, Desislava, Zornitsa, and Denitsa

\footnotetext{
4 Bulgarian names are transliterated according to the Bulgarian Law for Transliteration.

5 Until 1989 there were lists of recommended names, and parents were not allowed to choose an anthroponym that was not included in them. Naturally, there were exceptions.

6 According to their origin, Bulgarian first names are divided into four groups: common Slavic, Christian (Hebrew, Greek, or Latin), domestic, and borrowed from other languages (Ilchev 2012 [1969]).
} 
became popular (Choleva-Dimitrova 2002).

There is a trend as well when it comes to the use of borrowed first names. In 1960s, '70s and '80s Bulgaria, modern equalled foreign in people's perceptions. This tendency was amplified in the 1990s. The preferred forms of Bulgarian names changed to their foreign counterparts: Kristina instead of Hristina, Elizabet instead of Elisaveta, etc. This is how modernized names developed (Choleva-Dimitrova 2002: 283).

\subsection{Contemporary naming tendencies}

Currently, name giving and name choice in Bulgaria have been studied in few empirical studies (Yanev 2009; Virkkula 2014; Levkova 2019). Sociolinguistic methods are well suited to ensuring the obtainment of reliable data regarding this exceptionally multidimensional process. Boryan Yanev's socio-anthroponymic study was published in the beginning of the new century. It sought to identify the motivation behind name choices in Plovdiv - the second biggest city in Bulgaria for the period 2000-2005 (Yanev 2009). The author defined the following leading motivations: ancestral, traditional, exotic, and harmonious-sounding.

The results of this study indicate that two kinds of naming motivations prevail: randomly chosen names and traditional ones, i.e. renewing the name of ancestors, parents, family members, or individuals close to the family. Although the author ranks randomly chosen names in first place $(26.2 \%)$, it becomes clear that the share of traditional names is larger $(38.2 \%){ }^{8}$

Johanna Virkkula (2014) investigates the reasons behind name choices in the city of Sofia in approximately the same period. ${ }^{9}$ Based on the data obtained from the respondents, she identifies the most frequent reasons stated for name choice to be beautiful name $(57 \%),{ }^{10}$ named after a relative $(45.3 \%)$ and hereditary name (43.3\%) (Virkkula 2014: 75).

From the studies discussed above, it seems clear that Bulgarians preserve their powerful respect for the elderly. It is particularly common for parents to honour elders by using the first letter of their name when naming newborns (e.g. Viktor after Valkan, Diana after Dimitrinka) (Yanev 2009: 60). In other cases, parents please the grandparents by resorting to complex combinations derived from two names. As mentioned above, hybrid names became widespread primarily after the

7 The names of 500 newborns were used in the study, and their parents answered questionnaires. Additional polls at the BGmamma forum were also conducted (Yanev 2009).

8 The author presents the percentage of names given after grandfathers and grandmothers on the mother's side and the percentage of those on the father's side separately (Yanev 2009: 66).

9 The author based her conclusions on 361 questionnaires (Virkkula 2014: 51). By filling in selfadministered questionnaires, parents of young children (attending kindergarten) answered a series of questions in order to explain why they had chosen that particular name for their child.

10 Virkkula concludes that under "beautiful name" people usually understand an aggregation of etymological meaning, positive connotations, and aesthetic features such as euphony/ sound harmony, brevity, the way it is written, the way it matches with the family name, etc. (Virkkula 2014: 132). 
1970s and appeared "not as an expression of the self-formational ability of the Bulgarian language, but as a way for young parents to avoid offending their own parents" (Chobanov 1990: 31) ${ }^{11}$. This fact also helps explain the more conservative structure of the male anthroponymic system and relates to the changes in female names, which are far more dynamic (see Table 1 and 2).

Table 1: Comparison between the top 15 female names in 1979 and 2007

\begin{tabular}{|c|c|c|c|c|}
\hline \multirow[t]{2}{*}{ № } & \multirow{2}{*}{\begin{tabular}{|l|} 
Top 15 female \\
names for 1979 \\
\end{tabular}} & \multicolumn{3}{|c|}{ Top 15 female names in Sofia, Varna, and Plovdiv for 2007} \\
\hline & & SOFIA & VARNA & PLOVDIV \\
\hline 1. & Мария/Mariya & Виктория/Viktoriya & Виктория/Viktoriya & Мария/Mariya \\
\hline 2. & Марийка/Mariyka & Никол/Nikol & Габриела/Gabriela & Bиктория/Viktoriya \\
\hline 3. & Иванка/Ivanka & $\begin{array}{l}\text { Александра/ } \\
\text { Aleksandra }\end{array}$ & Никол/Nikol & Габриела/Gabriela \\
\hline 4. & Елена/Elenа & Мария/Mariya & Симона/Simona & $\begin{array}{l}\text { Александра/ } \\
\text { Aleksandra }\end{array}$ \\
\hline 5. & $\begin{array}{l}\text { Надежда/ } \\
\text { Nadezhda }\end{array}$ & $\begin{array}{l}\text { Йоана/Yoana, } \\
\text { Йоанна/Yoannа }\end{array}$ & Мария/Mariya & $\begin{array}{l}\text { Елена/Elena, } \\
\text { Никол/Nikol }\end{array}$ \\
\hline 6. & Пенка/Penka & $\begin{array}{l}\text { Габриела/ } \\
\text { Gabriela }\end{array}$ & $\begin{array}{l}\text { Александра/ } \\
\text { Aleksandra }\end{array}$ & Йоана/Yоаппа \\
\hline 7. & Еленка/Elenka & Симона/Simonа & Йоана/Yoапа & Гергана/Gergana \\
\hline 8. & Цветанка/Tsvetanka & Калина/Kalina & Гергана/Gergana & Teodopa/Teodora \\
\hline 9. & $\begin{array}{l}\text { Mapzapumal } \\
\text { Margarita }\end{array}$ & Paя/Raya & Teодора/Teodora & $\begin{array}{l}\text { Ивайла/Ivayla, } \\
\text { Магдалена/ } \\
\text { Magdalena }\end{array}$ \\
\hline 10. & Aнка/Anka & Гергана/Gergana & Деница/Denitsa & $\begin{array}{l}\text { Моника/Monika, } \\
\text { Цветелина/ } \\
\text { Tsvetelina }\end{array}$ \\
\hline 11. & $\begin{array}{l}\text { Василка/ } \\
\text { Vasilka }\end{array}$ & Елена/Elena & $\begin{array}{l}\text { Рая/Raya, } \\
\text { Моника/Monika }\end{array}$ & $\begin{array}{l}\text { Златка/Zlatka, } \\
\text { Ванеса/Vanesa, } \\
\text { Анелия/Aneliya }\end{array}$ \\
\hline 12. & $\begin{array}{l}\text { Йорданка/ } \\
\text { Yordanka }\end{array}$ & Teодора/Teodora & $\begin{array}{l}\text { Анелия/Aneliya, } \\
\text { Елена/Elena }\end{array}$ & Симона/Simonа \\
\hline 13. & $\begin{array}{l}\text { Лиляна/ } \\
\text { Lilyana }\end{array}$ & Андрея/Andreуа & $\begin{array}{l}\text { Даная/Danaya, } \\
\text { Eма/Ema, } \\
\text { Лора/Lora, } \\
\text { Ралица/Ralitsa }\end{array}$ & $\begin{array}{l}\text { Десислава/ } \\
\text { Desislava }\end{array}$ \\
\hline 14. & Радка/Radka & $\begin{array}{l}\text { Яна/Yапа, } \\
\text { Магдалена/ } \\
\text { Magdalena }\end{array}$ & $\begin{array}{l}\text { Даниела/Daniela, } \\
\text { Марина/Marina }\end{array}$ & $\begin{array}{l}\text { Христина/Hristin, } \\
\text { Стефани/Stefani, } \\
\text { Лилия/Liliya, } \\
\text { Емилия/Emiliya, } \\
\text { Деница/Denitsa, } \\
\text { Даниела/Daniela }\end{array}$ \\
\hline 15. & Pocuųa/Rositsa & Coфия/Sofiya & Eлицаa/Elitsa & Иванка/Ivanka \\
\hline & $\begin{array}{l}\text { *According to } \\
\text { Kovachev (1987). }\end{array}$ & \multicolumn{3}{|c|}{ *According to Choleva-Dimitrova \& Yanev (2015). } \\
\hline
\end{tabular}

11 The translations into English of the quotations from non-English sources are done by the authors of the paper. 
Table 2: List of the top 15 female names in Sofia and Varna for 2014

\begin{tabular}{|c|c|c|}
\hline № & Sofia & Varna \\
\hline 1. & Виктория/Viktoriya & Bиктория/Viktoriya \\
\hline 2. & Никол/Nikol & Никол/Nikol \\
\hline 3. & Мария/Mariya & Габриела/Gabriela \\
\hline 4. & Coфияя/Sofiya & Александра/Aleksandra \\
\hline 5. & Александра/Aleksandra & Дария/Dariya \\
\hline 6. & Дария/Dariya & Paя/Raya \\
\hline 7. & Йоана/Yоапа & Мария/Mariya \\
\hline 8. & Paя/Raya & Симона/Simona \\
\hline 9. & Габриела/Gabriela & Йоанна/Yоаппа \\
\hline 10. & Калина/Kalina & Магдалена/Magdalena \\
\hline 11. & EMa/Ema & Моника/Monika \\
\hline 12. & Елена/Elena & Ивайла/Ivayla, Карина/Karina \\
\hline 13. & Карина/Karina & Елена/Elenа, Калина/Kalina, София/Sofiya \\
\hline 14. & Михаела/Mihaela & $\begin{array}{l}\text { Божидара/Bozhidara, Eма/Eта, Mихаела/Mihaela, } \\
\text { Николета/Nikoleta, Сияна/Siyana }\end{array}$ \\
\hline 15. & Сияна/Siyana & $\begin{array}{l}\text { Крисия/Krisiya, Кристина/Kristinam } \\
\text { Марина/Marina, Ния/Niya, Полина/Polina }\end{array}$ \\
\hline
\end{tabular}

An examination of anthroponymic records from the past years reveals that the female names that have maintained their popularity throughout the better part of the last 40 years are Mariya and Elena. The following onyms have fallen out of frequent use: Mariyka, Ivanka, Nadezhda, Penka, Elenka, Tsvetanka, Margarita, Anka, Vasilka, Yordanka, Lilyana, Radka, Rositsa. The tendency to disregard names ending in $-k(a)$, and similar names that are perceived as diminutive, is very strong. The near disappearance of the hypocorism Mariyka from the Bulgarian name pool complies with said trend. In the present day, the sound of names like Ivanka, Elenka, Penka, Tsvetanka, Anka, and Radka does not correspond to the aesthetic requirements of parents, and they prefer forms like Elena, Ivana, Anna, and Rada. It is likely that these forms will completely vanish in the near future. For a sense of perspective, it is worth mentioning that Ivanka was the third most common female name in Bulgaria in the 20th century (Kovachev 1987: 201). By 2007, the form Ivanka was present in the top 15 only in Plovdiv, where it took last place (Choleva-Dimitrova \& Yanev 2011: 111). Currently, the favoured forms of this name are the ancient Yoana and foreign loans such as Zhana, Dzhovana, or the modified Ivanela, Ivanina, Ivandzhelina, etc.

The name Anna is still frequently encountered, including in many double forms such as Anna-Mariya, etc., while the anthroponyms Nadezhda, Margarita, Vasilka, Yordanka, Lilyana, and Rositsa cannot be found among the frequently used.

In the last few years, there has been a steady tendency to choose the name Victoriya. This may be due to the significance of its origin - the Latin word Victoria - in addition to its connection with popular personalities.

Over the last decades of the 20th century, the female names Nikol, Gabriela, and Aleksandra did not even place in the top 40 of most common 
female anthroponyms, in spite of the fact that the Bulgarian form of Nikol Nikolina - was thirty-second (Kovachev 1995: 597).

Male first names are characterized by a greater durability. The proportion of male anthroponyms that have consistently remained in the top 15 over the last 40 years is considerably larger than that of females. Georgi, Nikola, Nikolay, Dimitar, Teodor, and Ivan are still very popular, while Hristo, Petar, Vasil, Stefan, Stoyan, Atanas, Angel, Yordan, and Krasimir have become less common.

The names that have preserved their popularity over the past decade, and which were encountered in all the large cities surveyed, are: Aleksandra, Victoriya, Garbriela, Elena, Mariya, Yoana, Kalina, Nikol, Raya, and Simona. They are the top 10 names in Bulgaria today. It is notable that in the last decade, the changes are negligible and the same onyms have only exchanged positions. In the last few years, Victoriya is indisputably the most popular female name for Bulgarian newborn girls.

\subsubsection{Frequent names that have declined in the 21 st century}

Compared to the anthroponyms registered in 2007-2008, the lists from 2014-2015 do not contain the names Andrea or Yana, these having been replaced by the more modern-sounding Karina and Mihaela. The onyms that have decreased in popularity in Sofia are: Simona, Gergana, Teodora, Andrea, Yana, and Magdalena, while in Varna, such examples are: Gergana, Teodora, Denitsa, Aneliya, Danaya, Ralitsa, Daniela, and Elitsa.

Further analysis reveals some interesting aspects of the popularity dynamics of the compound names Bozhidara and Teodora. The Bulgarian form Todorka, which ranked 20th at the end of the last century, is seldom encountered today, having been replaced by the aforementioned Teodora. In 2009 , the name Bozhidara, which is a calque from Greek, was as common as the original Teodora, while in 2010, this Slavicized local version became the more preferred. In 2014, the name Teodora was no longer among the top 15 in Sofia and Varna, while Bozhidara was absent from the first 15 in Sofia. It was in 14th place in Varna.

The names that have increased in frequency since 2007 and which can be found among the top 15 are: Dariya, Ema, Karina, Mihaela, and Siyana. In the 20th century, the name Ema was in position 445/445. Its popularity in the present day is probably due to influences from cinema and literature, or it may be interpreted as a modern variant of Emiliya, Emili, Emanuela. The name Karina is known in Europe and is also perceived as modern. Such choices are commonly a sign of a striving for variety, and as a consequence, these anthroponyms undergo changes in form and sound composition.

In contrast to female names, where there has been a clear favourite for the last few years, the most popular male name is not as apparent. Data from the National Statistical Institute shows that two anthroponyms are in permanent competition for first place-Aleksandar and Georgi (National Statistical Institute). 
Aleksandar is unquestionably one of the most widespread names at the onset of the 21st century, especially in big cities. It is very often characterized as one that sounds good; parents seldom mention a historical personality as a motive for its choice (Choleva-Dimitrova \& Yanev 2015).

Georgi is considered to be one of the most genuinely Bulgarian names, in spite of its Greek origin, and St. Georgi is also one of the most venerated saints in Bulgaria. A comparison with 20th century records reveals that the onym has preserved its great popularity.

It should be noted that Ivan is no longer the most popular name among Bulgarians (NSI, danni za imenata 2019). The anthroponym Dimitar has also seen a drop in popularity, even though it was the most widespread one in Bulgaria during the second half of the 20th century. There is also a considerable decrease in the frequency of Todor, Vasil, Yordan, and Stefan, which were among the most preferred at the end of the 20th century (Kovachev 1987: 153). The last three onyms do not even reach the contemporary top 15. Another two names not present in the top 15 are Petar and Hristo, which occupied fourth and fifth place in the past century. In contrast, Nikola (the prevalent form) and Nikolay continue to enjoy great popularity.

The name Boris has also increased its presence, and it is now in the top 10 (NSI, danni za imenata 2019), up from 19th place at the end of the 20th century (Choleva-Dimitrova \& Yanev 2011). The names Kaloyan and Daniel also attained prominence in 2014.

Table 3: Dynamics of the top 15 male names in Sofia and Varna for 2014

\begin{tabular}{|c|c|c|}
\hline № & Sofia & Varna \\
\hline 1. & Александър/Aleksandar & $\begin{array}{l}\text { Александър/ } \\
\text { Aleksandar }\end{array}$ \\
\hline 2. & Мартин/Martin & Георги/Georgi, Мартин/Martin \\
\hline 3. & Георги/Georgi & Виктор/Viktor, Даниел/Daniel \\
\hline 4. & Никола/Nikola & Никола/Nikola \\
\hline 5. & Калоян/Kaloyan & Калоян/Kaloyan \\
\hline 6. & Борис/Boris & Николай/Nikolay \\
\hline 7. & Buкmop/Viktor & Борис/Boris \\
\hline 8. & Димитьр/Dimitar & Иван/Ivan \\
\hline 9. & Даниел/Daniel & Димитьр/Dimitar \\
\hline 10. & Николай/Nikolay & Teодор/Teodor \\
\hline 11. & Теодор/Teodor & Кристиян/Kristiyan \\
\hline 12. & Кристиян/Kristiyan & Симеон/Simeоn \\
\hline 13. & Иван/Ivan & Ивайло/Ivaylo \\
\hline 14. & Божидар/Bozhidar & Muхаил/Mihail \\
\hline 15. & Mихаил/Mihail & Божидар/Bozhidar, Самуил/Samuil \\
\hline
\end{tabular}




\section{Patronymics}

Despite officially existing only since the end of the 19th century, patronymic names were not unknown to Bulgarians earlier. They trace their origins to first name adjectives ending in -ov, $-e v,-i n$, but their function was limited to their use as possessive adjectives (Ilchev 2012 [1969]: 34). This expression of possession, however, went far beyond signifying whose son an individual was - it also conveyed successor status, whether this concerned property, occupation, or social rank.

According to Article 13 of the Civil Registry Law (Darzhaven vestnik 'Government Gazette' 2004), "the patronymic of each individual is formed from the father's first name and the suffix -ov or -ev, ending in accordance with the child's gender, except when the father's first name does not allow for the placement of these endings, or they go against the family, ethnic, or religious traditions of the parents" (Zakon za grazhdanskata registratsiya, bashtino ime 'Civil Registry Law, father's name'). The exemptions provided open the doors to many exceptions. In practice, patronymics without the suffixes -ov/-ev are increasingly widespread, e.g. Chavdar ${ }^{12}$ instead of Chavdarov(a), Anton instead of Antonov(a), Boyan instead of Boyanov(a), Grigor instead of Grigorov(a), etc. Research conducted by Choleva-Dimitrova \& VlahovaAngelova (2019) showed that 9.7\% of newborns in Sofia in 2014 were given patronyms without suffixes. This practice challenges the continuity of the formation of the patronymic and gives rise to concerns over its future existence in Bulgaria. Additionally, this uneven progression impedes the proper identification of individuals and has been an ever-increasing source of misunderstandings (Angelova-Atanasova 2005). In this context, cases in which the child's first name coincides with his patronymic name, as in Rosen Rosen Petrov, are particularly conspicuous (Simeonova 2005: 31).

The reasons for the heightened regularity of middle names without $-o v /$ $-e v$ are rooted in the shift in values experienced by Bulgarians in the last decades, when the transition from communism opened the traditionally conservative and relatively closed Bulgarian society to the process of globalization. The form of Bulgarian names suggests the bearer is in fact Bulgarian (Ilchev 2012 [1969]: 41). These days, some Bulgarians perceive names from which the endings $-o v /-e v$ are omitted as prestigious precisely because they sound more universal. For others, it is important that their offspring is not recognized as Bulgarian abroad, in order to ensure a smoother adaptation to a different culture. This also gives rise to a striving for international names. The particularities of Bulgarian orthography can also be a source of difficulties when transliterating a name, whether it be due to its proximity to a pejorative association or problems spelling and pronouncing it.

12 All examples of patronymics were taken from NSI data on newborns in Sofia in 2014. 
The majority of patronymics from which the suffix is omitted lack an objective reason for this, yet the suffix is omitted nevertheless. Even traditional Bulgarian names may be left unaltered: Boyko (5 times), Deyan (6 times), Lyuben (1 time). Written without a suffix, patronyms become ambiguous, in addition to not being innate to the Bulgarian anthroponymic system.

Another challenge faced by patronymic formation is the influx of borrowed male names, e.g. Kris, Richard, Charls, which have entered the Bulgarian anthroponymic system, yet have fallen short of adapting to its norms. Some proportions of these names do allow for the possibility of adding the suffixes, e.g. Dzheymsova $<$ Dzheyms, Paolova $<$ Paolo, Romeova $<$ Romeo, Rolandova $<$ Roland, but this remains impossible with others. Practice demonstrates that such anthroponyms are left without the -ov/-ev suffixes, e.g. Tomas (5 times), Maykal (2 times), Alfred (1 time).

Another formation challenge is posed by the now fashionable double and even triple first names, e.g. Yoan-Aleksandar ${ }^{13}$, Daniel-Konstantin, VictorEmanuel, Atanas-Stanislav. The formation of one name from two different first names is not extraneous to the Bulgarian anthroponymic system, where there are a number of family names composed from the father and grandfather's first names, e.g. Vasilstoyanov < Vasil and Stoyan, Vladigerov < Vlado and Gero (Ilchev 2012 [1969]: 36). This model could be applied to patronym formation from double first names: Daniel-Konstantin $>$ Danielkonstantinov ${ }^{14}$, ViktorEmanuel $>$ Viktoremanuelov, Atanas-Stanislav $>$ Atanasstanislavov.

Shortened diminutive forms have also increased in presence and could also be of concern. When patronymic names are formed from diminutive versions of a given name, the suffixes are often discarded, e.g. Toni $>$ Tonev (4 times) or Toniev (1 time), but also Toni (5 times).

\section{Family names}

Family names codify the entire history of a nation, with all the twists and the cultural and linguistic influences that have invariably affected it. They provide a direct link to the customs and traditions imposed over the centuries, the migration routes of the name bearers, as well as information about their daily lives. Family and patronymic names preserve the collective memory of each generation.

Family names officially became part of the Bulgarian anthroponymic system in the 19th century (Ilchev 2012 [1969]; Rusinov 1978; CholevaDimitrova 2017a: 14). Earlier Bulgarians used their kin names. The connection between kin names and family names is particularly profound, since a

13 Examples are from Sofia in 2014.

14 Such complex adjectives composed of two first names are easily formed in contemporary Bulgarian. 
considerable proportion of contemporary family names are actually heirs of older kin ones, which in their turn are based on forenames, bynames, and nicknames, as in: KN Shentovtsi > FN Shentovi, KN Katsartsi > FN Katsarski, KN Levatsi > FN Levachki (Choleva-Dimitrova 2017a: 13). Contemporary family names reflect a number of characteristics that act as an ethnic marker. Analogous to first names and patronymics, family names provide gender identification and carry enormously significant cultural information about the religion, ethnicity, and social status of the bearer.

According to the current law, the family name of every Bulgarian citizen is coined from the father's family name or the first name of the paternal grandfather (Zakon za grazhdanskata registratsiya, familno ime 'Civil Registry Law, family name'). In both cases, the common practice is for the family name to be clearly distinguishable from the first name (Ilchev 2012 [1969]: 35).

Structurally, Bulgarian family names are formed with the suffixes -ov, $-e v$, -ski, -in, -ich, the first two being predominant (Angelova-Atanasova 2005: 42). The female gender forms are correspondingly formed with -ova, -eva, -ska, -ina (Ilchev 2012 [1969]: 29-32). The fact that the family name is inherited implies that it is durable and less influenced by fashion/trends. Nonetheless, there is a process in Bulgaria in which old kin names preserved as family names are being lost (Choleva-Dimitrova 2017a).

The profound changes that occurred in Bulgarian society at the end of the 19th century led to the gradual decline of patriarchal kin relationships, and this in turn led to the abandonment of the principal kin name.

The fact that many Bulgarians renounced their kin names is interesting not only from a sociolinguistic perspective, but from a psychological one as well. The tendency to consciously give up kin names in favour of family names formed from the grandfather's first name is not new. It emerged in the mid20th century and has led to the gradual depersonalization of family names and a redundancy of the same appellations such as Petrovi, Ivanovi, Dimitrovi, etc. derived from frequent first names: Petar, Ivan, and Dimitar, respectively (Ilchev 2012 [1969]; Choleva-Dimitrova 2011, 2017b; Choleva-Dimitrova \& VlahovaAngelova 2019). This transformation was caused by the desire of Bulgarians to discard family names with a pejorative connotation and to eliminate anthroponyms of a foreign origin or to exchange them with their Bulgarian equivalent, e.g. Bakardzhiev > Mednikarov - med ('copper'), Terziev > Shivachev - shivach ('tailor') (Zaimov 1988). A significant number of family names are derived from kin names foreign in origin, mainly Turkish (as are the examples above), e.g. Avdzhiev < from dialect avdziya ('hunter') < Turkish avci ('hunter') (Ilchev 2012 [1969]: 48), Uzunov < Turkish uzun ('long, tall') (Ilchev 2012 [1969]: 680). In some cases, especially when based on nicknames, there truly are offensive qualifications, e.g. Kamburov $<$ Turkish kambur ('hunchback') (Ilchev 2012 [1969]: 42), Cholakov < Turkish çolak ('with a severed hand or fingers') (Ilchev 2012 [1969]: 736). Nowadays, they 
sound utterly incomprehensible to modern Bulgarians, and on occasion provoke a negative attitude or a sense of shame in the bearers. These purist pursuits originated during the National Revival (second half of the 19th century) and subsequently ebbed and flowed throughout different periods, which led to the translation of some family names and the disappearance of others.

The motives set forth in regard to the transformation of family names suggest a validation of the concerns in respect to the loss of identity in the Bulgarian anthroponymic system. Statistical data about the ten most common family names in the country published by the National Statistical Institute shows that, at the moment, most Bulgarians have family names such as Ivanov, Georgiev, Dimitrov, Petrov, Nikolov, Hristov, Stoyanov, Todorov, Iliev, and Angelov (NSI, danni za imenata 2019). This demonstrates that the most widespread family names in Bulgaria at the onset of the 21 st century are based on first names. These are neutral-sounding family names, and this is motivated by traditionally Bulgarian attitudes. Bulgarians feel the need to be part of the community, "to be like the others," and the question of "what would people say" is of paramount importance to them (Choleva-Dimitrova 2017a).

\section{Conclusions}

The studies conducted at the beginning of the 21 st century reveal the dynamics behind trends in naming fashions, which in turn allows us to examine the changes in naming motivations. Naming newborns after famous individuals from show business and sports, as well as characters from film or television, is a steady tendency from past years and is characteristic of all liberal anthroponymic systems around the world.

The inclination towards a preference for western-sounding names, the result of certain social trends, stands out clearly, e.g. Andzhelina is preferred over the Bulgarian form Angelina, Emili and Stefani over Emiliya and Stefka, Kristina over Hristina, and Teodor over Todor.

There are combinations of local and borrowed, traditional and new forms, as well as a number of recent additions. New anthroponymic formations continue to appear. There is much interest in compound names (coined following the Slavic manner) and the new appellations modelled on them, e.g. Boromir, Valemir, Rumislava, Tsvetodara, etc. Double names are becoming popular as well. Most of the double names in the research are foreign in origin. One of the most intriguing new and increasingly frequent trends in the formation of double or triple anthroponymic forms can be observed among female names in Sofia.

Names that have an accumulation of vowels, in addition to being short, are in fashion: Aya, Vaya, Dea, Deya, Lya, Kaya, Lea, Lia, Mia, Naya, Niya, Tea, Teya.

Names that have been consistently popular in the last 10 years can be encountered in all the cities included in the study: Aleksandra, Victoriya, 
Gabriela, Elena, Marya, Yoana, Kalina, Nikol, Raya, Simona. Out of the 10 most popular anthroponyms, 8 are of foreign origin: 4 of Hebrew origin - Mariya, Gabriela (Latinized version), Yoan(n)a, Simona; 3 from Greek - Nikol (French form), Aleksandra, Elena; and one of Latin origin - Victoriya. The different forms of the names transcend national borders, and even though the old Christian names are resilient, at present, the new borrowed forms are the preference.

The majority of the male names in fashion have kept their positions over time. The anthroponyms Georgi, Nikola, Nikolay, Teodor, and Ivan have preserved their relevance, and their usage endures.

The results obtained demonstrate the spread of modern influences. That the most popular contemporary names still contain appellations with enduring usage attests to the fact that concerns over the preservation of national identity may be unfounded. Bulgarian naming traditions are still alive today.

At present, the top 15 names constitute about $28-29 \%$ of the total number of female first names (for details see Choleva-Dimitrova \& Yanev 2015). Nonetheless, it is possible that unusual names could in the future exit the periphery and move toward the centre of the first name system, e.g. some newly formed and introduced onyms such as Svetliyana, Teodoriana, Teyana, Zarina; some borrowed names like Alehandra, Ameliya, Paula. It is precisely these names that delineate the modern trends and the two principal ways in which this process elapses: through the adoption of new imported and non-adapted anthroponyms and the creation of unique ones, which in some cases can be double or triple (Choleva-Dimitrova \& Dancheva 2018). The tendency towards unique names is on the rise in other countries as well (Lawson 2016: 189).

It is evident that the Bulgarian anthroponymic system has adopted certain international traits. Mainly under the influence of popular culture, many onyms that are popular worldwide are used. It must be noted that gender-neutral names have also entered the Bulgarian system, e.g. Aleks, Viki, Niki, etc.

In contrast to preceding historical periods, at present there is a great variety of first names.

The modern world is a place where distances are dwindling and some borders have decreasing significance. Moreover, if one of the meanings carried by the idea of globalization is the unpredictable, self-evolving character of the world, then the idea of universalization conveys the hope and intention to create orderliness (Bauman 1999: 82-83).

In the Bulgarian cultural and social medium, the subject of identity has become especially relevant as a national priority after the country's entry in the European Union. Every social change is inseparable from a shift in perceptions, if not for the whole of society, then at least for some social groups.

Even though the different naming practices from the 21st century described here indicate the modification, replacement, or displacement of Bulgarian anthroponyms by imports or new creations, we can conclude that Bulgarian naming traditions are alive and well today. 


\section{References}

Angelova-Atanasova, Mariya. 2005. Posoki i razvoy v imenuvaneto na balgarite $\mathrm{v}$ nachaloto na XXI vek [Directions and development in the name-giving of the Bulgarians at the beginning of the 21st century]. In Balkanski, Todor \& Burov, Stoyan \& Videnov, Mihail \& Koleva-Zlateva, Zhivka \& Selimski, Lyudvig (eds.), Sastoyanie i problemi na balgarskata onomastika [The current state and problems of Bulgarian onomastics], vol. 7, issue 1,34 45. Veliko Tarnovo: UI Sv. sv. Kiril i Metodiy.

Bankova, Petya. 2008. The given name - Sign of identification. In Marushiakova, Elena (ed.), Dynamics of national identity and transnational identities in the process of European integration, 130-137. Newcastle: Cambridge Scholars Publishing.

Bauman, Zigmunt. 1999. Globalizatziyata. Posleditzite za choveka [Globalization. Human consequences]. Sofia: Lik Publishing House.

Boyadzhiev, Zhivko. 1975. Kam vaprosa za hibridnite lichni imena [On the topic of Bulgarian hybrid personal names]. Balgarski ezik 25(3), 146-148.

Chobanov, Ivan. 1990. Nekotorye nablyudeniya nad vyborom imeni mal'chikov $\mathrm{u}$ bolgar [Some observations on name choice for Bulgarian children]. In Nauchni trudove na PU "Paisii Hilendarski" [Paisii Hilendarski University of Plovdiv - Bulgaria Research Papers], vol. 28, book 1, 1990, Languages and Literature, 25-32. Plovdiv: UI Paisiy Hilendarskiy.

Choleva-Dimitrova, Anna. 2002. Nablyudeniya varhu imenuvaneto v gr. Sofia [Some observations in naming trends in the city of Sofia]. In AngelovaAtanasova, Maria (ed.), Sastoyanie i problem na balgarskata onomastika [The current state and problems of Bulgarian onomastics], vol. 5, 279284. Veliko Tarnovo: UI Sv. sv. Kiril i Metodiy.

Choleva-Dimitrova, Anna. 2011. Rodovite imena u balgarite [Kin names of the Bulgarians]. Makedonski pregled 2 (1st part, A-D), 65-86; 3 (2nd part, E-Ya), 69-112.

Choleva-Dimitrova, Anna. 2017a. Narodopsihologiyata, otrazena v rodovite imena na balgarite [About the folk psychology reflected in kin names of the Bulgarians]. Balgarski ezik 4, 9-33.

Choleva-Dimitrova, Anna. 2017b. Sapostavka na antroponimiyata v golemiya grad i malkite naseleni masta [Name pool comparison between big cities and small settlements]. Institutziya i kompetentnost v ezika, literaturata i obrazovanieto, 55-66.

Choleva-Dimitrova, Anna \& Dancheva, Nadezhda. 2018. Lichnite imena v Sofia i Varna prez 2014 godina [Personal names in Sofia and Varna in 2014]. In Aleksova, Krasimira et al. (eds.), Problemi na sotziolingvistikata [Sociolinguistic issues], vol. 13, Obshtestvenite protzesi $i$ tyahnoto otrazhenie $v$ ezika [Public processes and their reflection in language], 122-128. Sofia: INSOLISO. 
Choleva-Dimitrova, Anna \& Vlahova-Angelova, Maya. 2019. Sastoyanie i problem na balgarskata lichnoimenna sistema [The current state and problems of the Bulgarian personal names system]. Balgarski ezik $i$ literatura 4, 373-389.

Choleva-Dimitrova, Anna \& Yanev, Boryan. 2011. Moda na lichnite imena v golemite balgarski gradove [About the personal name trends in big Bulgarian cities]. In Angelov, Angel G. \& Aleksova, Krasimira \& Kantcheva, Pavlina \& Issa, Katya \& Tsankov, Kiril (eds.), Problemi na sotziolingvistikata [Sociolinguistic issues], vol. 13, Obshtestvenite protzesi $i$ tyahnoto otrazhenie $v$ ezika [Public processes and their reflection in language. Proceedings of the Tenth International Sociolinguistic Conference Dedicated to Academician M. Videnov's 70th anniversary], 106-115. Sofia: Znak'94.

Choleva-Dimitrova, Anna \& Yanev, Boryan. 2015. Savremennata balgarska antroponimna sistema (moda na lichnite imena) [The contemporary Bulgarian anthroponymic system (Fashion in personal names)], part 1. Sofia/Plovdiv: Horizonti.

Darzhaven vestnik [Government Gazette]. 2004. (https://dv.parliament.bg/ DVWeb/broeveList.faces). (Accessed 2020-01-15.)

Debus, Friedhelm. 1997a. Personennamengebung der Gegenwart im historischen Vergleich. Kleinere Schriften 2, 696-771.

Debus, Friedhelm. 1997b. Zur Pragmatik von Namengebung und Namengebrauch in unzerer Zeit. Kleinere Schriften 2, 634-671.

Ilchev, Stefan. 2012 (1969). Rechnik na lichnite i familnite imena u balgarite [Dictionary of Bulgarian forenames and family names], 2nd edition. Sofia: Iztok-Zapad.

Kalkanova, Tatyana. 1996. Populyarno li e tvoeto ime? [How popular is your name?]. Sofia: UI Sv. Kliment Ohridski.

Konduktorova-Valkanova, Anastasiya. 1981. Nachini za obrazuvane na lichni imena ot slavyanski proizhod $v$ savremennata balgarska onomastika. Avtoreferat [Patterns for the formation of personal names of Slavonic origin in contemporary Bulgarian onomastics. Author's report]. Veliko Tarnovo: n.p.

Konstantinov, Yulian. 1987. Nyakoi vaprosi na balgarskata antroponimiya v sapostavitelen plan [Some issues in the Bulgarian anthroponymy in comparative terms]. Contrastive linguistics 12(4), 36-44.

Koss, Gerhard. 1990. Namenforschung. Eine Einführung in die Onomastik. Tübingen: Max Niemeyer Verlag.

Kovachev, Nikolay. 1987. Chestotno-talkoven rechnik na lichnite imena u balgarite [Thesaurus of Bulgarian personal names]. Sofia: Izd. D-r Petar Beron.

Kovachev, Nikolay. 1995. Chestotno-etimologichen rechnik na lichnite imena $v$ savremennata balgarska antroponimiya [Etymological dictionary of personal names in Bulgarian contemporary anthroponymy]. Veliko Tarnovo: PIK. 
Krasteva-Blagoeva, Evgeniya. 1999. Lichnoto ime v balgarskata traditziya [The personal name in the Bulgarian tradition]. Sofia: AI Prof. M. Drinov.

Krysteva, Anna. 1998. Etnichnost [Ethnicity]. In Krysteva, Anna (ed.), Obshtnosti $i$ identichnosti $v$ Balgaria [Communities and identity in Bulgaria], 9-48. Sofia: Izd. Pekston.

Lawson, Edwin D. 2016. Personal naming systems. In Hough, Carole \& Izdebska, Daria (eds.), The Oxford handbook of names and naming, 169199. Oxford: Oxford University Press.

Levkova, Rada. 2019. Motivi za izbor na lichno ime v nachaloto na XXI vek [Grounds for a personal name choice at the beginning of 21st century]. In Bondzolova, Valentina et al. (eds.), Nomen est omen, 395-416. Veliko Tarnovo: University Publishing Sv. sv. Kiril i Metodiy.

Natzionalen statisticheski institut [National Statistical Institute]. (https://www.nsi. bg/bg/search/node/names) (Accessed 2020-01-31.)

NSI, danni za imenata 2019 [NSI, name data 2019]. (https://www.nsi.bg/sites/ default/files/files/pressreleases/Names2019p.pdf) (Accessed 2020-01-06.)

NSI, Prebroyavane 2011 (okonchatelni danni) [NSI, 2011 census (final data)]. (https://www.nsi.bg/census2011/NPDOCS/Census2011final.pdf)

(Accessed 2020-01-31.)

Rusinov, Rusin. 1978. Familni imena v savremenniya balgarski knizhoven ezik [Family names in the contemporary Bulgarian standard language]. In Pomagalo po balgarska morfologiya. Imena [A textbook of Bulgarian morphology. Names]. Sofia: n.p.

Simeonova, Nelly. 2005. Prakticheski problemi na formiraneto na imenata u balgarite $\mathrm{v}$ sluzhbite na GRAO [Practical problems about name formation of the Bulgarians observed by GRAO Service]. In Balkanski, Todor \& Burov, Stoyan \& Videnov, Mihail \& Koleva-Zlateva, Zhivka \& Selimski, Lyudvig (eds.). Sastoyanie $i$ problem na balgarskata onomastika [The current state and problems of Bulgarian onomastics], vol. 7, issue 1, 29-33. Veliko Tarnovo: UI Sv. sv. Kiril i Metodiy.

Superanskaya, Aleksandra. 1973. Obshchaya teoriya imeni sobstvennogo [General theory of proper names]. Moskva: Nauka.

Taylor, Charles. 1999. Multikulturalizam [Multiculturalism]. Sofia: Izd. kashta KH. Van Langendonck, Willy. 1971. Über die Theorie des Eigennamens. Onoma $16,87-91$.

Van Langendonck, Willy. 1980. Über die Pragmatisierung der Namenkunde. BNF. NF. 15, 286-294.

Virkkula, Johanna. 2014. First Name Choices in Zagreb and Sofia. Helsinki: University of Helsinki. (Slavica helsingiensia, 44.) (https://helda.helsinki.fi/ bitstream/handle/10138/135867/firstnam.pdf?sequence=1\&isAllowed) (Accessed 2019-11-23.) 
Yanev, Boryan. 2009. Sistema na lichnite imena v balgarskiya i nemskiya ezik [The system of personal names in Bulgarian and German]. Plovdiv: UI Paisiy Hilendarskiy.

Zaimov, Yordan. 1988. Balgarski imennik [Bulgarian onomasticon]. Sofia: BAN. Zakon za grazhdanskata registratsiya, bashtino ime [Civil Registry Law, father's name]. (https://www.lex.bg/laws/ldoc/2134673409) (Accessed 2020-01-15.) Zakon za grazhdanskata registratsiya, familno ime [Civil Registry Law, family name]. (https://www.lex.bg/laws/ldoc/2134673409) (Accessed 2020-01-15.)

Zakon za transliteratziyata [Law for transliteration]. (https://www.lex.bg/ laws/ldoc/2135623667) (Accessed 2020-01-31.) 